\title{
Constitutional recognition: French perspective
}

\section{Clara Goutaudier}

University of Technology Sydney, Faculty of Arts and Social Sciences, PO Box 123, Ultimo NSW

2017, Australia.clara.goutaudier@student.uts.edu.au

DOI: $\underline{\text { https://doi.org/10.5130/nesais.v4i1.1513 }}$

The Constitution of France is based on principles from the 1789 revolution, stating in its first article that it is an "indivisible republic" and that it "ensures the equality before the law of all citizens without distinction of origin, race or religion." Growing up in such a unitary country (as opposed to multicultural), it was hard for me to completely grasp the idea of recognition of indigenous groups, of ethnic or cultural minorities. Yet, France recently recognised the existence of such local groups in territories outside the mainland - for instance, New-Caledonia. It mostly refers to memorial issues, reflecting on "the shadows of colonial times", and further affirmative action. This draws on the concept of the 'right to recognition' theorised by Le Pourhiet (2014), with objective principles of cultural diversity and the grant of collective rights to more vulnerable groups.

Reflected in the Australian context, recognition in the Constitution is in my mind necessary but not sufficient. It is necessary because the Constitution is a "birth certificate of nation" according to the Attorney-General Hon. Robert McClelland (About Constitutional Recognition | Australian Human Rights Commission, 2011), and so it is incomplete if no mention is made of the histories of peoples who lived here for thousands of years prior to European settlement. Recognition would be a symbolic gesture towards reconciliation, with a federal power acknowledging the darkest shadows of its past and committing to take action for a better future. Symbols are indeed important in nation-building; they enrich the collective identity and advance Australia as a democracy by ensuring the protection of the rights of all Australians.

However, I believe it is not sufficient because Aboriginal and Torres Strait Islander peoples today still suffer from discrimination and exclusion, and a mere symbolic recognition will not have concrete consequences to remedy that. Indeed, the current Constitution contains no protection against racial discrimination. The Constitution should be amended to offer a legal protection from unjust laws. Because Australia is a federal state, I think there is a need for treaties at the State level, as it would have substance and not be merely symbolic. States have the powers to act on issues that matter, such as housing, education or health. There is moreover a need of Aboriginal representation at the State level, ensuring that the voices of previously unheard minorities are championed. Such treaties would be agreements on issues of sovereignty, the relationship between Aboriginal and Torres Strait Islander peoples and the government, the rights of those communities and the decision-making process. 
Australia therefore faces complicated issues in recognising its past and its Indigenous groups and at the same time ensuring the health of its democracy and national unity.

\section{References}

About Constitutional Recognition | Australian Human Rights Commission n.d., Humanrights.gov.au. viewed 1 June 2018, <https://www.humanrights.gov.au/publications/about-constitutionalrecognition>.

Castan, M. 2014, Explainer: what Indigenous constitutional recognition means, The Conversation. viewed 1 June 2018, <https://theconversation.com/explainer-what-indigenous-constitutionalrecognition-means-31770>.

Le Pourhiet A., Le droit constitutionnel de la reconnaissance, Civitas Europa, 2014/1 (№32), p. 3753. DOI: https://doi.org/10.3917/civit.032.0037. < https://www.cairn.info/revue-civitas-europa-20141-page-37.htm>.

Little, A. and McMillan, M. 2016, On the wrong track: why Australia's attempt at Indigenous reconciliation will fail, The Conversation. viewed 1 June 2018, <https://theconversation.com/on-thewrong-track-why-australias-attempt-at-indigenous-reconciliation-will-fail-58064>.

(c) (i) (C) 2018 by the author(s). This article is distributed under the terms and conditions of the Creative Commons Attribution license (http://creativecommons.org/licenses/by-nd/4.0/). 